\title{
ICT Used In Education Sector Considering Primary and Secondary Level Schools in Rural Areas: A Study of Sylhet Division in Bangladesh
}

\author{
Md.Mahbobor Rahaman ${ }^{1,}$ Naznine Akter ${ }^{2}$ \\ ${ }^{I}$ (Lecturer, Dept. of Business Administration, Leading University, Sylhet, Bangladesh) \\ ${ }_{2}^{2}$ (Lecturer, Dept. of Business Administration, Ranada Prasad Shaha University, Bangladesh)
}

\begin{abstract}
Information and communication technology (ICT) can play a vital rule in every shapes of human life even in where human can't imagine. ICT may change the way of livelihood and education system of a country in a radical way. The urban people easily get the benefits of ICT but rural sides are till now legging behinds of this. This paper mainly focuses the ICT used on primary and secondary educational level schools in rural areas of Bangladesh. Though the rural primary and secondary schools are suffering hundreds of problems in compare with urban schools, ICT can partially minimize the discrimination of this problem. This research mainly presents the current ICT status on rural primary and secondary schools of Sylhet division in Bangladesh.
\end{abstract}

Keywords: Education, ICT, Primary School, Remote Areas, Secondary School.

\section{Introduction}

ICT can play a vital role not only in urban areas but also in remote areas. As our country is agro based country most of the people of our country till now live in rural areas. So any development will be incomplete without the development of this part. The development of any country is totally depending on the development of educational sector. The country of Bangladesh is land of natural beauty and most of the people are living in rural areas. Rural people are deprived from the all technological advancement but they have the right to access on this sector.ICT on rural area can change the image of Bangladesh. If we want to change Bangladesh with technological advancement, then we must develop the core educational sector of this country. Primary and secondary education can play a vital role for development of any country. The role of primary and secondary education is very important in every nation. In Bangladesh the ICT application and ICT adaptation in primary and secondary level is also critical. In this paper the focus point of ICT in rural areas specially in Sylhet division (Digital Bangladesh, 2016). This division is totally surrounded by the various large and small hills and water locked areas. The communication process is very difficult in these areas. The data collection and survey was a challenging task. We can't imagine the development process of these remote areas. The government of Bangladesh has been taken various steps for making the digital Bangladesh. In every primary government school has at least one laptop and multimedia systems. The primary schools of remote area are well equipped by the modern technology but the application of this technology is very rare.

\section{Objective of the Study}

The main objective of this paper is the ICT penetration on primary and secondary level educational institutions in rural areas of Bangladesh. Moreover, the other key objectives of this study are

1. To find out the current ICT status on rural area's primary and secondary schools in Sylhet division.

2. To find out the main challenges and prospects of ICT on rural area's primary and secondary schools.

\subsection{Survey Design and Conduction of Survey}

\section{Research Methodology}

Mainly the primary source is used to collect the information for conducting the research. Moreover, the secondary source is also used for collecting data. To fulfill the main objectives of this research, primary data has been collected by using closed and open ended questionnaires and schedules. The main questionnaires are divided into two major parts one is for teachers and other students. Collection of data through schedules is used for students. The sample was analyzed by the Complex Stratified Sampling (CSS). From remote areas of Sylhet division in Bangladesh 399 primary and secondary schools are considered as a sample size. SPSS 20.0 software is used for analyzing the data for fulfilling the objectives of the research. 


\subsection{Study Areas}

The study was conducted in 32Upazilas (the third highest tier of regional administration) from four districts (the second highest tier of regional administration) such as Sylhet, Habiganj, Sunamgonj and Maulvibazar of Sylhet division (the highest tier of regional administration) in Bangladesh. The sample schools of this 32Upazilas all are located on the rural side of each four districts of Sylhet.

\begin{tabular}{|c|l|l|l|l|l|}
\hline \multicolumn{6}{|c|}{ Sylhet Divisions } \\
\hline Number of Divisions & $\begin{array}{l}\text { Number of } \\
\text { Districts }\end{array}$ & $\begin{array}{l}\text { Number of } \\
\text { Upazila }\end{array}$ & $\begin{array}{l}\text { Number of Union } \\
\text { Pasishad }\end{array}$ & $\begin{array}{l}\text { Number of } \\
\text { Schools }\end{array}$ & $\begin{array}{l}\text { Number of } \\
\text { Teachers }\end{array}$ \\
\hline 1 & 4 & 32 & 200 & 253 & 400 \\
\hline
\end{tabular}

\subsection{Data Collection}

Data was collected through structured questionnaire, direct site observation and face-to-face conversation and also semi-structured questionnaire. A sample size of 253 schools from the remote areas of Sylhet divisions was chosen for this study in Bangladesh. Most of the interviewees were asked structured questions about the use of ICT, challenges and opportunities with a view to generate stories of their experience regarding the ICT application in their schools. Some examples of questions that were asked include 'How many computer or laptop do you have in your school?', 'Do you use internet in your school?', What are the main problems for adapting ICT in your school?' etc. In addition, some secondary data also collected from various related web sites and books.

\section{Literature Review}

ICT can play a vital role not only in urban areas but also in remote areas (Khan, Hadi, \& Ashraf, 2013). As our country is agro based country most of the people of our country till now live in rural areas. So any development will be incomplete without the development of this part.ICT has a significant impact on rural areas (Khan, Hadi, \& Ashraf, 2013).The huge population only will be an asset when it will be properly educated and modernized (Ali M. , 2003).Technology can minimize digital divide with ensure the sustainable development. ICTs are now widely accepted tool to development issues in developing countries (Most, 2015).

ICT may enhance teachers' knowledge for developing skills for curriculum integration, pedagogic practices through the use of lesson planning, learning techniques and interactive teaching technique (Mridha, Nihlen, Khan, Islam, Sultana, \& Reza, 2013). Teachers' awareness regarding the ICT also a critical fact in teaching and learning process that can be helpful for ICT adaptation in rural areas schools (Ali R., 2015).

Bangladesh is developing countries and also it has a lack of the resources and appropriate infrastructure for implementing ICT in education specially in rural areas. Sufficient equipment, computer supply and its various components and sufficient supply of electricity would be required for ICT use in rural areas of Bangladesh (Khan, Hasan, \& Clement, 2012). Only ICT can minimize the gap between the rural and urban areas development. A cost-effective ICT based solution for economic development of rural community in developing countries using ICT based education systems can reach the Bangladesh as a develop country (Islam, Shafik, Hassa, \& Son, 2006).ICTs can reduce communication costs and break down geographical borders not only for Bangladesh but also for all over the world (Rahman, 2015).By using this advantages Bangladesh can improve in their educational sector. Technologies enhance students to work productively than in the traditional class room but the teacher's role in technology rich classrooms is more demanding (Keengwe, 2008).ICT has improved the teaching and learning process, teacher's work design and interactive student and teacher learning process.

ICT has the potential to improve the educational system and ICT in the classroom can improve the student performance in every aspect of their student life (Kessy, 2006).In education the impact of ICT is very high. The ICT based class room is more interactive than any other class room, students can capture the difficult things in a very easy way which also very durable for them. Sometimes ICT will be an integral part for development of rural education in where there is no capable teaching staff. By applying the benefit of ICT, we are able to give training, use video conferencing, audiovisual communication and communicate via satellite for the rural areas of Bangladesh (Ashraf, Grunfeld, Afza, \& Malik, 2011).

\section{Analysis}

Bangladesh has made a vision to make a digitalized country. To full fill this dream all sectors are being made digitalized for this reason. Among the 253 rural schools from various union porishad of Sylhet, Habiganj, Sunamgonj and Maulvibazar district were selected for survey (sylhetdiv.gov.bd, 2017). All the schools in very remote areas are considering for this study. The Sylhet is a land of natural beauty. Most of the people are living in aboard. The living standard in this division is much diversified. Per capita income in this areas are totally depending on foreign remittance. There is a large number of people also living below the standard of their living standard. They have no land, capital or any other resources lo live their life. 


\subsection{Demographic characteristics}

\begin{tabular}{|l|l|}
\hline Area & $3490 \mathrm{~km}^{2}$ \\
\hline Upazila Road: & $805.23 \mathrm{~km}$ \\
\hline Union Road: & $821.11 \mathrm{Km}$ \\
\hline Village Road: & $3332.91 \mathrm{Km} \mathrm{VA}, 2999.95 \mathrm{Km} \mathrm{VB}$ \\
\hline Population: & $35,67,138(2011)$ \\
\hline Density: & 1045 per sq. kmKm${ }^{2}$ \\
\hline Literacy: & $51.20 \%$ \\
\hline No. of Upazila: & 13 \\
\hline No. of Union: & 101 \\
\hline No. of Pourashava: & 4 \\
\hline No. of Primary School: & 1066 \\
\hline No. of High School: & 277 \\
\hline No. of College: & 59 \\
\hline No. of Universities & 6 \\
\hline
\end{tabular}

Source: (Bnaglapedia, 2015)

\subsection{Data Analysis}

Table 1. Do you use computer in your school?

\begin{tabular}{|ll|c|c|c|c|}
\hline & Frequency & Percent & Valid Percent & Cumulative Percent \\
\hline Valid & Yes & 134 & 53.0 & 53.0 & 53.0 \\
& No & 119 & 47.0 & 47.0 & 100.0 \\
& Total & 253 & 100.0 & 100.0 & \\
\hline
\end{tabular}

In table. 1 it was fond that among 253 rural schools only 134(53\%) use at least one computer in their school and other 119(47\%) don't use any computer. That means less than half of the total rural schools are out of ICT and modern technology facilities.

Table 2.Do you Use Internet in your school?

\begin{tabular}{|ll|c|c|c|c|}
\hline & Frequency & Percent & Valid Percent & Cumulative Percent \\
\hline Valid & Yes & 113 & 44.7 & 44.7 & 44.7 \\
& No & 140 & 55.3 & 55.3 & 100.0 \\
& 253 & 100.0 & 100.0 & \\
\hline
\end{tabular}

In table.2 it was fond that among 253 rural schools only 113(44.7\%) use internet in their school and other $140(55.3 \%)$ don't use internet. More than half of the schools that use computer but they don't use internet and internet facilities for their educational purpose.

Table 3.Number of Computer in Your School

\begin{tabular}{|ll|r|r|r|r|}
\hline & Frequency & Percent & Valid Percent & Cumulative Percent \\
\hline Valid & Nill & 52 & 20.6 & 20.6 & 20.6 \\
& One & 136 & 53.8 & 53.8 & 74.3 \\
& Two & 23 & 9.1 & 9.1 & 83.4 \\
Three & 5 & 2.0 & 2.0 & 85.4 \\
Four & 6 & 2.4 & 2.4 & 87.7 \\
Five & 5 & 2.0 & 2.0 & 89.7 \\
Seven & 10 & 4.0 & 4.0 & 93.7 \\
Ten & 3 & 1.2 & 1.2 & 94.9 \\
Eleven & 3 & 1.2 & 1.2 & 96.0 \\
Others & 10 & 4.0 & 4.0 & 100.0 \\
Total & 253 & 100.0 & 100.0 & \\
\hline
\end{tabular}

It was shown that from the Table.3 maximum number of schools 53.8\% (among 253 schools) have only one computer in their school, $20.6 \%$ don't have any computer,9.1\% have two computers, only $4 \%$ school have more than twelve. 
Table 4.Do you have computer knowledge (individual teacher)?

\begin{tabular}{|ll|r|r|r|r|}
\hline & Frequency & Percent & Valid Percent & Cumulative Percent \\
\hline Valid & 0 & 4 & 1.6 & 1.6 & 1.6 \\
& Yes & 139 & 54.9 & 54.9 & 56.5 \\
& No & 109 & 43.1 & 43.1 & 99.6 \\
3 & 1 & .4 & .4 & 100.0 \\
Total & 253 & 100.0 & 100.0 & \\
\hline
\end{tabular}

In Table 4. It was shown that only $54.9 \%$ have computer knowledge, this knowledge regarding the basic knowledge of computer for example only how to operate the computer. The deep knowledge of computer was very little among the surveyed students. That means there is a huge lack of computer and ICT related teachers in the rural areas.

Table 5.Main problem for ICT adaptation in your school

\begin{tabular}{|ll|r|r|r|r|}
\hline & Frequency & Percent & Valid Percent & Cumulative Percent \\
\hline Valid & 164 & 64.8 & 64.8 & 64.8 \\
& Lack of ICT Teacher & 46 & 18.2 & 18.2 & 83.0 \\
Lack of Interest on ICT. & 9 & 3.6 & 3.6 & 86.6 \\
Lack of money. & 4 & 1.6 & 1.6 & 88.1 \\
Not related to text book. & 20 & 7.9 & 7.9 & 96.0 \\
Cannot use computer by the teacher. & 4 & 1.6 & 1.6 & 97.6 \\
Computer training is expensive & 6 & 2.4 & 2.4 & 100.0 \\
Others. & 253 & 100.0 & 100.0 & \\
Total & & & &
\end{tabular}

To adapt ICT in rural schools, have many problems among all the problems lack of ICT teachers is the first rank. From the Table 5 It was shown that $64.8 \%$ percent schools don't any ICT or Computer teachers or even they have any training on ICT or computer components. Another important problem was lack of interest on ICT because most of the teachers from the rural areas think that IC]T and computer is very complicated matter and it is very difficult to understand.18.2\% teachers among the rural areas don't have any interest on ICT. To test the level of significance, lack of ICT teachers is highly significant. Below the Table 6 it is shown that $73.9 \%$ respondents were given the highest priority on lack of ICT teachers. That means among 253 respondents 187 talk about they have no ICT teachers or expert.

Table 6.Lack of ICT Teacher

\begin{tabular}{|ll|r|r|r|r|}
\hline & Frequency & Percent & Valid Percent & Cumulative Percent \\
\hline Valid & Most Significant & 187 & 73.9 & 73.9 & 73.9 \\
& Significant & 34 & 13.4 & 13.4 & 87.4 \\
Average & 27 & 10.7 & 10.7 & 98.0 \\
Not relevant & 5 & 2.0 & 2.0 & 100.0 \\
Total & 253 & 100.0 & 100.0 & \\
\hline
\end{tabular}

Table 7.Lack of Interest on ICT

\begin{tabular}{|ll|r|r|r|r|}
\hline & Frequency & Percent & \multicolumn{1}{|c|}{ Valid Percent } & Cumulative Percent \\
\hline Valid & Most Significant & 163 & 64.4 & 64.4 & 64.4 \\
& 48 & 19.0 & 19.0 & 83.4 \\
& Significant & 23 & 9.1 & 9.1 & 92.5 \\
Average & 11 & 4.3 & 4.3 & 96.8 \\
Not Relevant & 8 & 3.2 & 3.2 & 100.0 \\
Do not know & 253 & 100.0 & 100.0 & \\
Total & & & & \\
\hline
\end{tabular}


The lack of interest on ICT was also significant. It was shown that among 253 respondents schools 163 said that they have on interest on ICT and computer or modern technology. From the Table 7 It was shown that $64.4 \%$ respondents were given the high level of significant.

Table 8.Lack of money

\begin{tabular}{|ll|r|r|r|r|}
\hline & Frequency & Percent & Valid Percent & Cumulative Percent \\
\hline Valid & Most Significant & 141 & 55.7 & 55.7 & 55.7 \\
& Significant & 42 & 16.6 & 16.6 & 72.3 \\
Average & 62 & 24.5 & 24.5 & 96.8 \\
Not Relevant & 8 & 3.2 & 3.2 & 100.0 \\
Total & 253 & 100.0 & 100.0 & \\
\hline
\end{tabular}

Another important problem of ICT adaptation in primary and secondary schools in rural areas was lack of money. The level of significant of financial crisis is very high. It was shown that from the Table 8 total $55.7 \%$ schools are suffering from money. They don't have sufficient money to purchase ICT or computer related materials.

Table 9.Not related to text book

\begin{tabular}{|ll|r|r|r|r|}
\hline & Frequency & Percent & Valid Percent & Cumulative Percent \\
\hline Valid & Most Significant & 29 & 11.5 & 11.5 & 11.5 \\
& Significant & 36 & 14.2 & 14.2 & 25.7 \\
Average & 113 & 44.7 & 44.7 & 70.4 \\
Not relevant & 51 & 20.2 & 20.2 & 90.5 \\
Do not know & 24 & 9.5 & 9.5 & 100.0 \\
Total & 253 & 100.0 & 100.0 & \\
\hline
\end{tabular}

In primary level there is no computer related topics in their text book but it has no impact on ICT adaption. From Table 9 it was shown that the level of significant was only $11.5 \%$. So there are no barriers in ICT adaption even the text book has no introduction about computer.

Table 10.Cannot use computer by the teacher

\begin{tabular}{|ll|r|r|r|r|}
\hline & Frequency & Percent & Valid Percent & Cumulative Percent \\
\hline Valid & Most Significant & 154 & 60.9 & 60.9 & 60.9 \\
& Significant & 50 & 19.8 & 19.8 & 80.6 \\
Average & 39 & 15.4 & 15.4 & 96.0 \\
.Not relevant & 10 & 4.0 & 4.0 & 100.0 \\
Total & 253 & 100.0 & 100.0 & \\
\hline
\end{tabular}

From the Table 10 it was shown that most of the rural areas teachers $(60.9 \%$ almost $70 \%)$ cannot use computer and they have any ability to operate computer or computer related technology.

Table 11.Computer training is expensive

\begin{tabular}{|ll|r|r|r|r|}
\hline & Frequency & Percent & Valid Percent & Cumulative Percent \\
\hline Valid & Most Significant & 24 & 9.5 & 9.5 & 9.5 \\
& Significant & 55 & 21.7 & 21.7 & 31.2 \\
Average & 66 & 26.1 & 26.1 & 57.3 \\
Not relevant & 50 & 19.8 & 19.8 & 77.1 \\
Do not know & 58 & 22.9 & 22.9 & 100.0 \\
Total & 253 & 100.0 & 100.0 & \\
\hline
\end{tabular}

From the Table 11 it was shown that the level of significant is only $9.5 \%$ regarding computer training and it's cost. So this factor is not related to adapt ICT on primary and secondary school in rural areas. 
Table 12. Others

\begin{tabular}{|ll|r|r|r|r|}
\hline & Frequency & Percent & Valid Percent & Cumulative Percent \\
\hline Valid & Most Significant & 103 & 40.7 & 40.7 & 40.7 \\
& Significant & 20 & 7.9 & 7.9 & 48.6 \\
Average & 59 & 23.3 & 23.3 & 71.9 \\
Not relevant & 49 & 19.4 & 19.4 & 91.3 \\
Do not know & 22 & 8.7 & 8.7 & 100.0 \\
Total & 253 & 100.0 & 100.0 & \\
\hline
\end{tabular}

Without mentioned this factor all other factors are on the other categories. The level of significant of the others is relatively low. From the Table 12 the significant level was $40.7 \%$.

\section{Findings and Recommendations}

There were many findings available in this study but all were not equally important. Some of the key findings and recommendations of this study are presenting here.

i. More computers and ICT related materials should be supplied each and every schools in rural areas.

ii. Rural schools are totally deprived of Internet facilities for this reasons all schools should be introduced internet facilities.

iii. The awareness regarding the blessing of ICT and Internet should be introduced to all teachers and students in the rural schools.

iv. Government and NGOs should come forward to financially support the rural schools in Bangladesh.

v. In the text curriculum ICT and computer knowledge should be introduced from the very begging of their student life.

vi. Government, private organizations and NGOs should arrange a comprehensive computer and ICT training program for all the teachers in rural areas.

vii. Ministry of education should closely supervise all the rural schools regularly.

\section{Conclusion}

ICT and education are closely related to each other. The blessing of ICT can also be helpful on the education systems and effective of education of any country not only the remote area in Bangladesh. The study mainly finds out the real impact of ICT on human behavior from the very beginning of their life even they live in the remote areas. Though the government of Bangladesh tries to adapt ICT in every shape of their citizen's life, the real impact is too small. Most of the schools have computer or laptop but they are lagging behind only for expert in ICT. From this study maximum schools don't have any ICT teachers nor ICT trained teachers for teaching the ICT of rural students. The study sometimes can't find out the proper information due to unawareness regarding ICT of the respondents.

\section{References}

[1]. Digital Bangladesh. (2016, December 31). Retrieved January 30, 2017, from bangladesh.gov.bd http://bangladesh.gov.bd/site/page/fc63120c-63e9-406f-904a-48e399ca0f79/

[2]. Khan, A. R., Hadi, R. S., \& Ashraf, D. M. (2013). The Impact of ICT on Education: A Study on Rural Schools. Communications in Information Science and Management Engineering , 3 Iss. (8), 367-368.

[3]. Ali, M. (2003). ICT EDUCATION CASE STUDY. Asian South Pacific Bureau of Adult Education (ASPBAE), ASPBAE Research on Information and Community Technology , 4-6.

[4]. Most, T. M. (2015). A Statistical Case Study of using ICT in Educational Sector in Rural Context of Bangladesh. Global Journal of HUMAN-SOCIAL SCIENCE: C Sociology \& Culture, 15 (3 Version 1.0), 25-27.

[5]. Mridha, M., Nihlen, G., Khan, A. A., Islam, M. S., Sultana, N., \& Reza, S. (2013). E-Learning for empowering the rural people in Bangladesh: Opportunities and challenges. IEEE, 323.

[6]. Ali, R. (2015). ICT Using Situation in Rural and Urban Primary Schools of Bangladesh: A Comparative Study. Education \& Literacy Curriculum Manage. Dhaka,Bangladesh: FH Association, Bangladesh.

[7]. Khan, M. S., Hasan, M., \& Clement, C. K. (2012). BARRIERS TO THE INTRODUCTION OF ICT INTO EDUCATION IN DEVELOPING COUNTRIES: THE EXAMPLE OF BANGLADESH. International Journal of Instruction , 5 (2), $62-64$.

[8]. Islam, A. R., Shafik, R. A., Hassa, M., \& Son, B. J. (2006). Next Generation Rural Wireless Connectivity Model for Developing Countrie. IEEE , 3-5

[9]. Rahman, M. A. (2015). Access to Global Information-A case of Digital Divide in Bangladesh .

[10]. Keengwe, J. G. (2008). Computer Technology Intragration and Student Learning:Barriers and Promise. Journal of Science Education and Technology, 16 (6), 560-565.

[11]. Kessy, D. K. (2006). The Reasons for under use of ICT in education:In the context of Kenya,Tanzania and Zambia. 4th IEEE Internatinal Cnferance on Technology for Education in Developing Countries,Iringa,Tanzania., (pp. 24-26). Iringa.

[12]. Ashraf, M., Grunfeld, H., Afza, S. R., \& Malik, B. (2011). Information Communication Technology (ICT) for Rural Women's Life in Bangladeshi Village. IGI Global , 172-175.

[13]. sylhetdiv.gov.bd. (2017, May 14). Retrieved May 25, 2017, from sylhetdiv.gov.bd: http://www.sylhetdiv.gov.bd/site/view/primary school/

[14]. Bnaglapedia. (2015, March 12). http://en.banglapedia.org/index.php?title=Sylhet_Division. Retrieved from banglapedia.org: http://en.banglapedia.org/index.php?title=Main_Page 